\title{
Spatio-temporal appearance of -amylase and limit dextrinase in barley aleurone layer in response to gibberellic acid, abscisic acid and salicylic acid.
}

\author{
Shahpiri, Azar; Talaei, Nasim; Finnie, Christine
}

Published in:

Journal of the Science of Food and Agriculture

Link to article, DOI:

10.1002/jsfa.6695

Publication date:

2015

Document Version

Publisher's PDF, also known as Version of record

Link back to DTU Orbit

Citation $(A P A)$ :

Shahpiri, A., Talaei, N., \& Finnie, C. (2015). Spatio-temporal appearance of -amylase and limit dextrinase in barley aleurone layer in response to gibberellic acid, abscisic acid and salicylic acid. Journal of the Science of Food and Agriculture, 95(1), 141-147. https://doi.org/10.1002/jsfa.6695

\section{General rights}

Copyright and moral rights for the publications made accessible in the public portal are retained by the authors and/or other copyright owners and it is a condition of accessing publications that users recognise and abide by the legal requirements associated with these rights.

- Users may download and print one copy of any publication from the public portal for the purpose of private study or research.

- You may not further distribute the material or use it for any profit-making activity or commercial gain

- You may freely distribute the URL identifying the publication in the public portal 


\title{
Spatio-temporal appearance of $\alpha$-amylase and limit dextrinase in barley aleurone layer in response to gibberellic acid, abscisic acid and salicylic acid
}

\author{
Azar Shahpiri, ${ }^{a *}$ Nasim Talaei ${ }^{a}$ and Christine Finnie ${ }^{b}$
}

\begin{abstract}
BACKGROUND: Cereal seed germination involves mobilization of storage reserves in the starchy endosperm to support seedling growth. In response to gibberellin produced by the embryo the aleurone layer synthesizes hydrolases that are secreted to the endosperm for degradation of storage products. In this study analysis of intracellular protein accumulation and release from barley aleurone layers is presented for the important enzymes in starch degradation: $\alpha$-amylase and limit dextrinase (LD).

RESULTS: Proteins were visualized by immunoblotting in aleurone layers and culture supernatants from dissected aleurone layers incubated up to $72 \mathrm{~h}$ with either gibberellic acid (GA), abscisic acid (ABA) or salicylic acid (SA). The results show that $\alpha$-amylase is secreted from aleurone layer treated with GA soon after synthesis but the release of LD to culture supernatants was significantly delayed and coincided with a general loss of proteins from aleurone layers.
\end{abstract}

CONCLUSIONS: Release of LD was found to differ from that of amylase and was suggested to depend on programmed cell death (PCD). Despite detection of intracellular amylase in untreated aleurone layers or aleurone layers treated with ABA or SA, $\alpha$-amylase was not released from these samples. Nevertheless, the release of $\alpha$-amylase was observed from aleurone layers treated with GA+ABA or GA+SA.

(C) 2014 Society of Chemical Industry

Supporting information may be found in the online version of this article.

Keywords: barley; aleurone layer; appearance patterns; plant hormones; $\alpha$-amylase; limit dextrinase

\section{INTRODUCTION}

In cereal seeds the carbohydrates and proteins stored in the non-living starchy endosperm cells are mobilized during germination for use by the developing seedling. ${ }^{1}$ Upon imbibition, the aleurone layer cells, which remain alive in the mature grain, synthesize and secrete a range of enzymes, including hydrolases, for depolymerization of endosperm cell walls ${ }^{2,3}$ and degradation of endosperm storage products. ${ }^{4}$ Complete hydrolysis of starch, the major carbohydrate reserve in cereal seeds, requires the action of four enzyme activities: ${ }^{5} \alpha$-amylase is the key enzyme that specifically attacks endo- $\alpha-1,4-$ glucosidic bonds to produce a range of linear and branched maltodextrins; $\beta$-amylase removes maltose from the non-reducing ends of maltodextrins and starch polymers; the debranching enzyme limit dextrinase (LD), also known as pullulanase, catalyses hydrolysis of $\alpha$-1,6-glucosidic bonds; ${ }^{6}$ and $\alpha$-glucosidase (maltase) converts maltose to glucose. ${ }^{3-7}$

Limit dextrinase activity is of particular importance for the brewing industry as the branched dextrins produced after the action of $\alpha$-amylase on starch are not fermentable and represent a loss of potential ethanol production. A number of factors are suggested to be responsible for the modest activity of LD during germination and the malting process. ${ }^{8,9}$ These include complex formation with the limit dextrinase inhibitor in the starchy endosperm ${ }^{10}$ and inhibition by maltooligosaccharides. ${ }^{11}$

While $\beta$-amylase is synthesized during seed development and stored in the starchy endosperm, ${ }^{12-14}$ de novo synthesis of hydrolases involved in starch degradation is induced in the aleurone layer in response to gibberellin produced by the embryo after seed imbibition. Abscisic acid (ABA) has an antagonistic effect on gibberellin action and suppresses the expression of genes encoding hydrolytic enzymes in aleurone layers. However, ABA stimulates expression of many genes that may function in stress tolerance and seed dormancy. ${ }^{15}$

Salicylic acid (SA) is a critical signalling molecule that modulates plant responses to pathogen infection and regulates

\footnotetext{
Correspondence to: Azar Shahpiri, Department of Agricultural Biotechnology, College of Agriculture, Isfahan University of Technology, Isfahan-84156-83111, Iran.E-mail:a.shahpiri@cc.iut.ac.ir

a Department of Agricultural Biotechnology, College of Agriculture, Isfahan University of Technology, Isfahan 84156-83111, Iran

b Agricultural and Environmental Proteomics, Department of Systems Biology, Technical University of Denmark, DK-2800 Kgs, Lyngby, Denmark
} 
diverse aspects of plant responses to abiotic stresses through extensive signalling cross-talk with other growth hormones. ${ }^{16-20}$ Furthermore, genetic studies using various Arabidopsis mutants have demonstrated that SA exerts its role in a variety of plant developmental processes through coordinate interactions with gibberellins, ABA, jasmonic acid (JA), and ethylene. ${ }^{21,22} \mathrm{SA}$ also plays a role in germination under stressful conditions, although its precise role and the underlying molecular mechanisms involved have not been fully elucidated. ${ }^{22,23}$ It has been reported that SA inhibits seed germination in a dosage-dependent manner in maize (Zea mays), ${ }^{24}$ Arabidopsis ${ }^{25}$ and barley (Hordeum vulgare). ${ }^{26}$

Isolated aleurone layers provide a unique system for analysis of responses to plant hormones because the aleurone layer: (i) does not synthesize endogenous hormones, but can respond strongly to exogenously added gibberellic acid (GA) or ABA; (ii) is composed of a single cell type that responds uniformly to hormones; (iii) is easily separated from the other seed tissues; and (iv) can be isolated, and maintained as well as manipulated in culture medium. The isolated aleurone layer experimental system allows analysis of both intracellular proteins and the release of hydrolytic enzymes accumulating in the culture supernatant. ${ }^{27-29}$

In the present study, isolated aleurone layers were maintained in culture medium. This isolated system enables monitoring of the effects of GA, ABA and SA on the protein appearance patterns of $\alpha$-amylase and LD, which are two key hydrolytic enzymes involved in starch degradation. The data presented here provide new insights into the role of the aleurone layer in regulation of starch degradation in the endosperm and forms the basis for monitoring the changes in aleurone layer proteome in response to hormones.

\section{EXPERIMENTAL}

\section{Plant material}

Seeds from barley cultivar Fajr 30 were prepared from Isfahan Center for Research of Agriculture Science and Natural Resources. The embryo-containing part of the seeds was cut away from the rest of the seeds with a sharp scalpel. The embryoless half grains were sterilized with $70 \%$ ethanol for $1 \mathrm{~min}$, followed by washing five times with sterilized water. The seeds were then soaked for 4 days in sterile water with $50 \mu \mathrm{g} \mathrm{mL}^{-1}$ ampicillin and $5 \mu \mathrm{g} \mathrm{mL}^{-1}$ nystatin. The seed coat was removed, the endosperm was scraped away from the aleurone layers and $100 \mathrm{mg}$ (fresh weight) aleurone layers were incubated in $2 \mathrm{~mL}$ buffer $\left(20 \mathrm{mmol} \mathrm{L}^{-1} \mathrm{CaCl}_{2}, 20 \mathrm{mmol}\right.$ $\mathrm{L}^{-1}$ Na succinate $\mathrm{pH} 4.2,50 \mu \mathrm{gmL}^{-1}$ ampicillin, $5 \mu \mathrm{gmL}^{-1}$ nystatin).
Where required, either $\mathrm{GA}\left(5 \mu \mathrm{mol} \mathrm{L} \mathrm{L}^{-1}\right), \mathrm{ABA}\left(20 \mu \mathrm{mol} \mathrm{L} \mathrm{L}^{-1}\right)$ or $\mathrm{SA}$ ( $20 \mu \mathrm{mol} \mathrm{L}^{-1}$ or $1 \mathrm{mmol} \mathrm{L}^{-1}$ ) was added to the medium. Incubation up to $72 \mathrm{~h}$ was performed at room temperature with continuous gentle shaking. Aleurone layers were harvested at various time points, washed four times with incubation buffer without antibiotics or hormones, frozen in liquid nitrogen and stored at $-80^{\circ} \mathrm{C}$ until use. For analysis of proteins released from aleurone layers, the culture supernatants were collected, clarified by centrifugation, transferred to new tubes and stored at $-80^{\circ} \mathrm{C}$ until use.

\section{Protein extraction}

Frozen aleurone layers (100 mg fresh weight) were dried under vacuum and ground to a fine powder using a pre-cooled ceramic mortar and pestle. The powder was resuspended in $600 \mu \mathrm{L}$ ice-cold extraction buffer $\left(5 \mathrm{mmol} \mathrm{L}^{-1}\right.$ Tris $\left.-\mathrm{HCl}, 1 \mathrm{mmol} \mathrm{L}^{-1} \mathrm{CaCl}_{2}, \mathrm{pH} 7.5\right)$ containing $4 \mu \mathrm{L}^{\text {ProteoBlock }}{ }^{\mathrm{TM}}$ protease inhibitor cocktail (Fermentas) and transferred to an Eppendorf tube. Two glass beads were added to aid homogenization of the tissue. The samples were shaken for $30 \mathrm{~min}$ at $4{ }^{\circ} \mathrm{C}$ and centrifuged ( $2 \mathrm{~min}, 10000 \times \mathrm{g}$, $4{ }^{\circ} \mathrm{C}$, then $10 \mathrm{~min}, 24000 \times \mathrm{g}, 4^{\circ} \mathrm{C}$ ) to remove debris. Supernatants $(500 \mu \mathrm{L})$ were transferred to clean tubes. The total protein concentrations in extracts were determined by the Bradford assay with bovine serum albumin as standard. ${ }^{30}$ Since the concentration of proteins in supernatants was low, the proteins in culture supernatants were precipitated. To this end $4 \mathrm{~mL}$ of $10 \%(\mathrm{w} / \mathrm{v})$ TCA in acetone was added to $1 \mathrm{~mL}$ supernatant from each sample. The proteins were allowed to precipitate overnight at $-20^{\circ} \mathrm{C}$. Samples were then centrifuged and the pellet was washed with acetone. Residual acetone was removed by air drying. Pellets were then dissolved in $250 \mu \mathrm{L}$ extraction buffer.

\section{Sodium dodecyl sulfate-polyacrylamide gel electrophoresis (SDS-PAGE) and western blotting}

For SDS-PAGE and western blotting proteins in $18 \mu \mathrm{L}$ aleurone layer extracts were separated on 12\% Tris-glycine SDS-PAGE. Gels were stained with silver nitrate. ${ }^{31}$ For western blotting, proteins were transferred to a PVDF membrane (Roche Applied Science) according to the manufacturer's instructions. The blots were blocked overnight in blocking buffer containing $5 \%(\mathrm{w} / \mathrm{v})$ skimmed milk in TBST $\left(10 \mathrm{mmol} \mathrm{L}{ }^{-1} \mathrm{NaCl}, 25 \mathrm{mmol} \mathrm{L}^{-1}\right.$ Tris - $\mathrm{HCl}, \mathrm{pH} 7.5,0.1 \%$ (v/v) Tween 20). The primary antibodies - rabbit anti- $\alpha$-amylase raised against barley AMY2 (customer preparation, DAKO A/S, Denmark) and rabbit anti-LD ${ }^{32}$ - were diluted 1:1000 in TBST. The

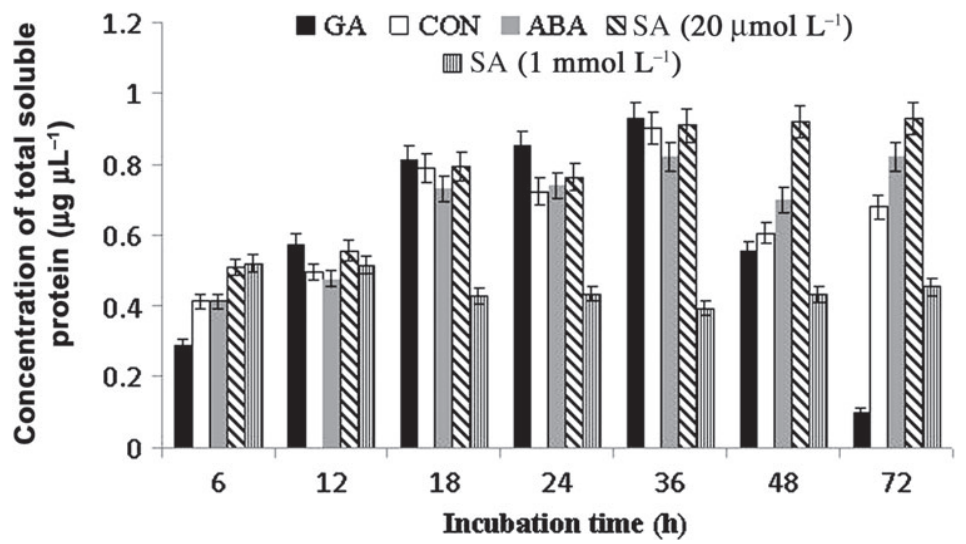

Figure 1. Changes in soluble protein concentrations of extracts from aleurone layers after incubation in $G A, A B A, S A\left(20 \mu \mathrm{mol} \mathrm{L}^{-1}, 1 \mathrm{mmol} \mathrm{L}^{-1}\right)$ and control for 6-72 h. Each histogram represents the mean \pm SD obtained from three independent experiments. 
antigen-antibody interaction was carried out at room temperature for $1 \mathrm{~h}$. The blots were washed $(3 \times 10 \mathrm{~min})$ with TBST followed by $(1 \times 10 \mathrm{~min})$ TBS $\left(10 \mathrm{mmol} \mathrm{L}{ }^{-1} \mathrm{NaCl}, 25 \mathrm{mmol} \mathrm{L}^{-1}\right.$ Tris $-\mathrm{HCl}, \mathrm{pH}$ 7.5). Blots were then probed with goat-anti-rabbit lgG conjugated with horseradish peroxidase (GenScript) diluted 1:2000 in TBST as secondary antibody. The membranes were washed again, as explained before. After washing the immunoblots were developed using $0.5 \mathrm{mg} \mathrm{mL}^{-1}$ diaminobenzidine in $50 \mathrm{mmol} \mathrm{L}^{-1}$ Tris $-\mathrm{HCl}, \mathrm{pH}$ 7 and $0.22 \%$ hydrogen peroxide.

A
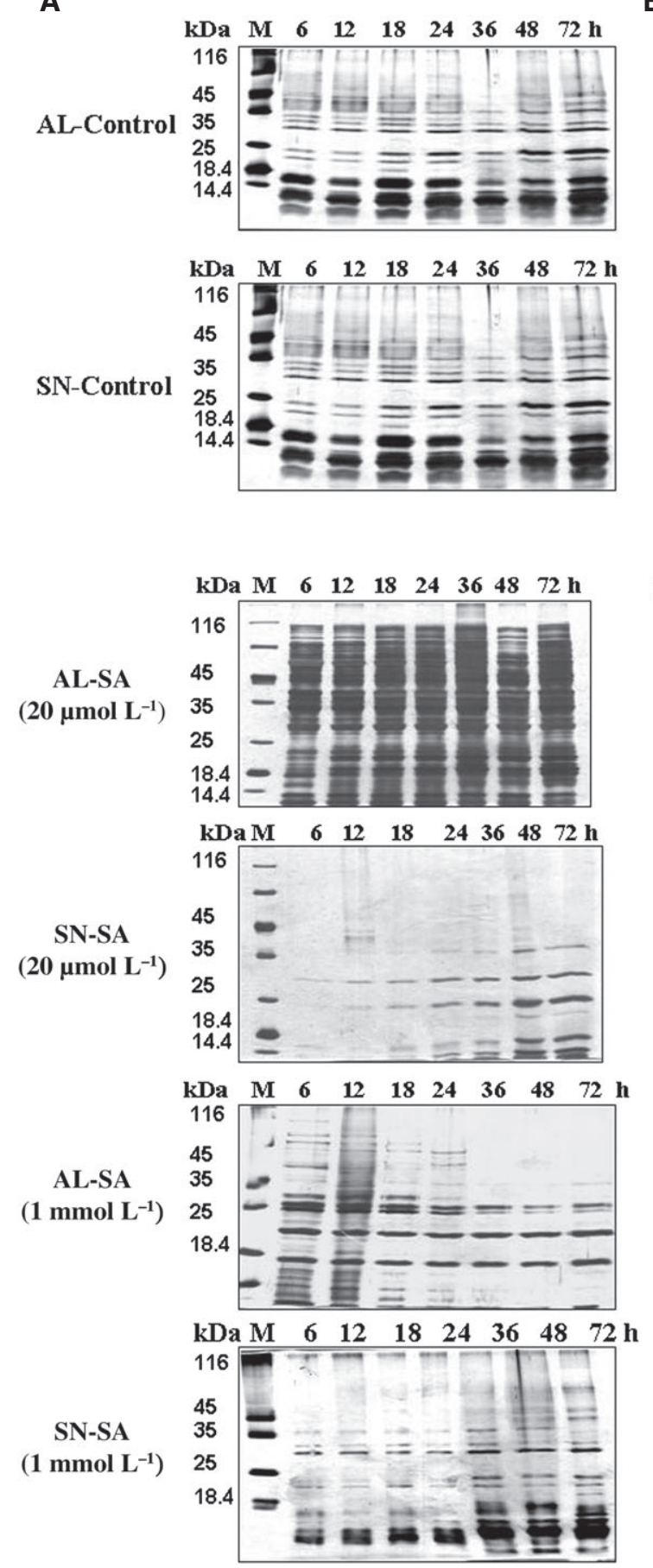

\section{RESULTS}

The changes in amount of total protein in aleurone layer in response to hormones

Soluble proteins were extracted from the same amount of aleurone layer treated with GA (AL-GA), ABA (AL-ABA), SA (AL-SA) 20 $\mu \mathrm{mol} \mathrm{L^{-1 }}$ or $1 \mathrm{mmol} \mathrm{L}^{-1}$ or buffer without hormones (AL-control) at different time points $(6-72 \mathrm{~h})$. The amount of total soluble protein extracted from AL-ABA, AL-GA and AL-SA $\left(20 \mu \mathrm{mol} \mathrm{L}^{-1}\right)$ was similar to that from $\mathrm{AL}$-control up to $48 \mathrm{~h}$. After $72 \mathrm{~h}$ the amount of total

B
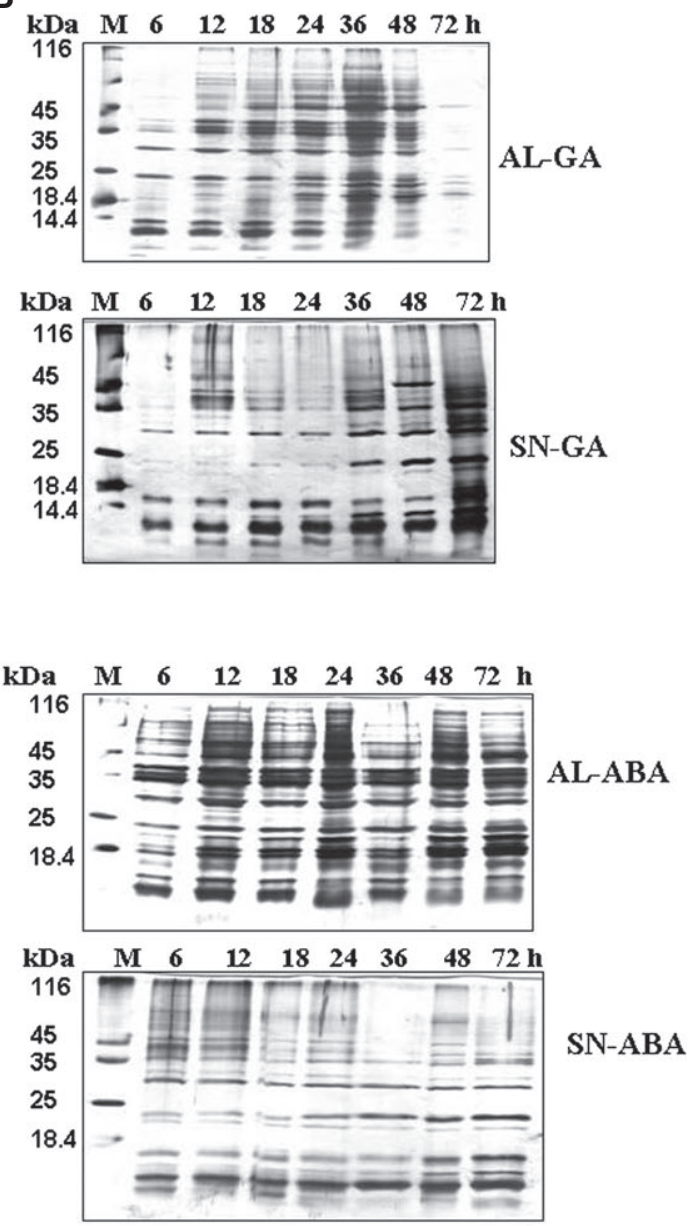

Figure 2. SDS-PAGE analysis of extracts from (A) AL-control, (B) AL-GA, (C) AL-SA and (D) AL-ABA and their corresponding culture supernatants during $6-72 \mathrm{~h}$ incubation. Equal volumes $(18 \mu \mathrm{L})$ of protein extract from aleurone layer or culture supernatant were loaded on to SDS-PAGE and stained with silver nitrate. 
protein significantly decreased in AL-GA compared to that from AL-control, AL-ABA and AL-SA $\left(20 \mu \mathrm{mol} \mathrm{L}^{-1}\right)$ (Fig. 1).

These changes in total extractable protein across samples were also visualized by SDS-PAGE, where equal volumes of aleurone layer extracts were loaded (Fig. 2). Culture supernatants corresponding to aleurone layers incubated in buffer with no hormones as well as aleurone layers incubated with either GA, SA at two concentrations ( $1 \mathrm{mmol} \mathrm{L}^{-1}$ and $20 \mu \mathrm{mol} \mathrm{L}^{-1}$ ) or ABA were also harvested, precipitated and equal volumes from different samples loaded on SDS-PAGE. The analysis of culture supernatants is considered to show the proteins released from aleurone layers into the starchy endosperm. This is a very important property of the aleurone layer culture system, which is difficult to analyse in intact seeds. The amount of protein in supernatants was low and similar for all treatments up to $48 \mathrm{~h}$. However, after $72 \mathrm{~h}$ incubation a higher amount of protein and increased number of protein bands were present in supernatants from GA-treated aleurone layers (Fig. 2B) in comparison with the supernatants from AL-control (Fig. 2A), AL-SA (Fig. 2C) and AL-ABA (Fig. 2D) .

Comparison of the protein pattern in the aleurone layer and culture supernatant demonstrated that the aleurone layer releases a large amount of its protein content after $72 \mathrm{~h}$ incubation with
A AL-Control, SDS-PAGE

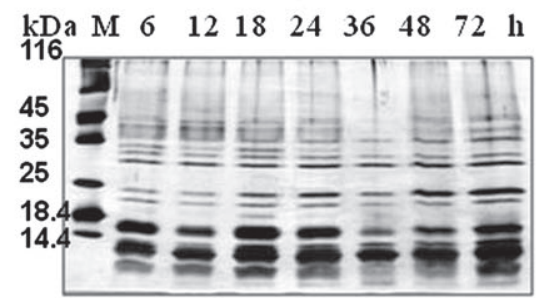

kDa M AL-Control, $\alpha$-amylase
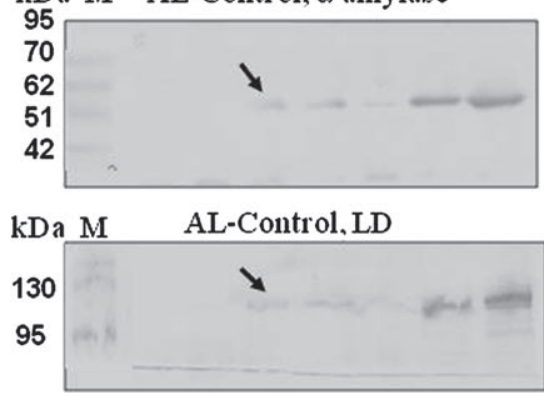

AL-GA, SDS-PAGE
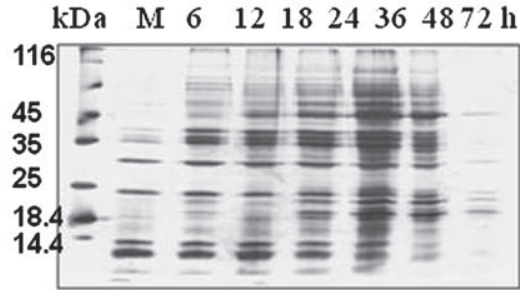

kDa $\mathrm{M} \quad \mathrm{AL}-\mathrm{GA}, \alpha$-amylase

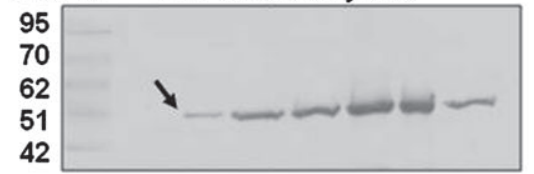

kDa $\mathrm{M} \quad \mathrm{AL}-\mathrm{GA}, \mathrm{LD}$

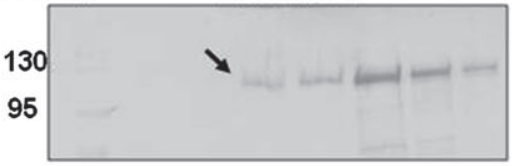

B SN-Control, SDS-PAGE

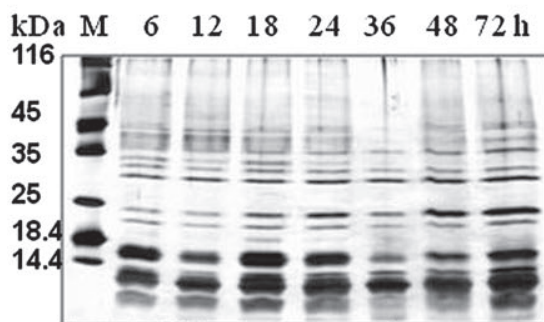

kDa M SN-Control, $\alpha$-amylase
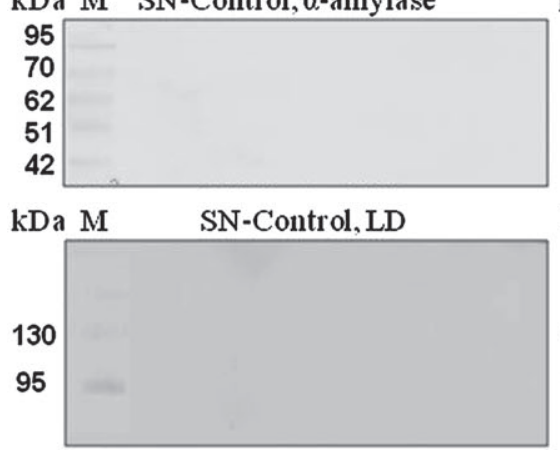

SN-GA, SDS-PAGE
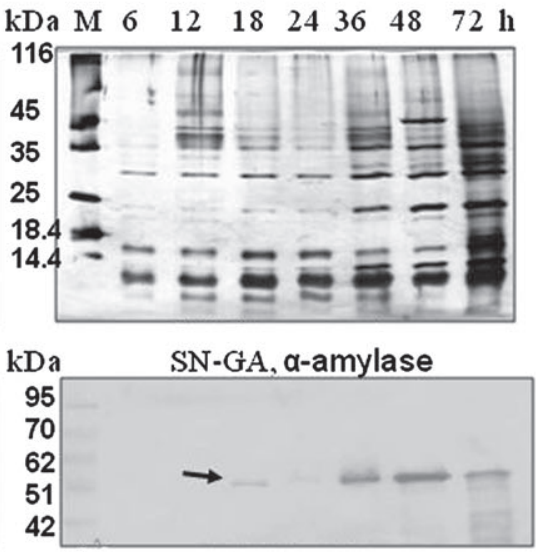

kDa M SN-GA, LD

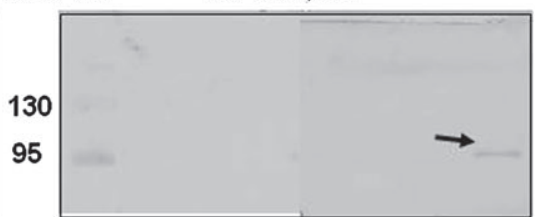

Figure 3. Time-course study of appearance patterns of $\alpha$-amylase and LD in (A) aleurone layer extracts and (B) culture supernatants treated with GA and control without hormone treatment (control) during 6-72 h incubation. Equal volumes $(18 \mu \mathrm{L})$ of protein extracts from aleurone layer or culture supernatant were loaded on to SDS-PAGE. Limit dextrinase (LD) and $\alpha$-amylase were detected by western blotting. The arrows show the position of $\alpha$-amylase and LD bands. 
GA, while it was postponed for AL-ABA, AL-SA $\left(20 \mu \mathrm{mol} \mathrm{L}^{-1}\right)$ and AL-control. These changes in AL-GA could be due to programmed cell death $(P C D)$ induced by GA. ${ }^{33}$ Therefore, PCD-regulated disintegration of aleurone cells after prolonged incubation in GA causes the release of intracellular proteins into the culture supernatants.

In comparison to AL-control, a low amount of total protein and decreased number of protein bands were observed in AL-SA (1 $\mathrm{mmol} \mathrm{L}^{-1}$ ), indicating the inhibitory effect of high SA concentration on protein synthesis in the aleurone layer. However, total extractable protein and the number of protein bands in aleurone layers treated with physiological concentration of SA $(20 \mu \mathrm{mol}$ $\mathrm{L}^{-1}$ ) was even higher than in AL-control at different time points, suggesting that SA at this concentration may induce the synthesis of new proteins in the aleurone layer (Fig. 2C).

\section{Synthesis and release of $\alpha$-amylase and LD in aleurone layer treated with GA}

Western blotting showed that $\alpha$-amylase was present in aleurone layer extracts after $12 \mathrm{~h}$ incubation with $\mathrm{GA}$, and its abundance increased up to $48 \mathrm{~h}$ (Fig. 3A). The amount of $\alpha$-amylase decreased after $72 \mathrm{~h}$ in parallel with the decrease in extractable water-soluble protein at this time point. In comparison to GA-treated samples, low levels of $\alpha$-amylase were detected in control samples from 18 $\mathrm{h}$, and the amount increased up to $72 \mathrm{~h}$. This is in agreement with a previous study showing that transcripts of $\alpha$-amylase are present in the unstimulated aleurone cells and increase after stimulation with $\mathrm{GA} \cdot{ }^{34}$

Low levels of LD were detected in aleurone layer extracts after 18 $h$ in GA, which increased very clearly at $36 \mathrm{~h}$, followed by a decrease up to $72 \mathrm{~h}$. LD was hardly detected in control aleurone layers but increased considerably after $48 \mathrm{~h}$ incubation (Fig $3 \mathrm{~A}$ ). This may be explained by the synthesis and storage of LD in an insoluble form during seed development, ${ }^{9-35}$ which is not easily extracted under the present conditions, but which may be converted to a soluble, extractable form during the incubation period. In fact, a previous study showed that LD is synthesized as an inactive bound form and is converted to an active free form during germination. ${ }^{36}$

Culture supernatants from aleurone layers incubated with GA or without hormones were also harvested, precipitated and equal volumes from different samples loaded on SDS-PAGE. Western blotting was used to monitor the appearance of proteins in aleurone culture supernatants. The $\alpha$-amylase was detected in culture supernatants after $18 \mathrm{~h}$ incubation with GA (Fig. 3B), shortly after its detection in aleurone layer extracts (Fig. 3A), and its abundance increased up to $48 \mathrm{~h}$ (Fig. 3B). No $\alpha$-amylase, however, was detected in $\mathrm{SN}$-control (Fig. $3 \mathrm{~B}$ ), despite the presence of the protein in AL-control aleurone layer extracts (Fig. 3A). In contrast to $\alpha$-amylase, the release of LD from the aleurone layer into the culture supernatant occurred much later than its detection inside the aleurone layer and was only detected after $72 \mathrm{~h}$ in SN-GA (Fig. 3B). At this time the aleurone layer treated with GA is likely to be undergoing PCD and releases most of its protein contents (Fig. 2B). As was the case for $\alpha$-amylase, LD was not detected in supernatants from AL-control (Fig. 3B), despite the presence of the protein in $\mathrm{AL}$-control aleurone layer extracts (Fig. $3 \mathrm{~A}$ ).

\section{Effects of ABA and SA on synthesis and release of GA-induced $\alpha$-amylase and LD}

Both $\alpha$-amylase and LD were faintly detected in AL-ABA ( $20 \mu \mathrm{mol}$ $\mathrm{L}^{-1}$ ) after $18 \mathrm{~h}$ incubation (Fig. S1, supporting information). Their amounts were increased after $48 \mathrm{~h}$ incubation as in control samples, indicating the presence of low amounts of amylase and LD

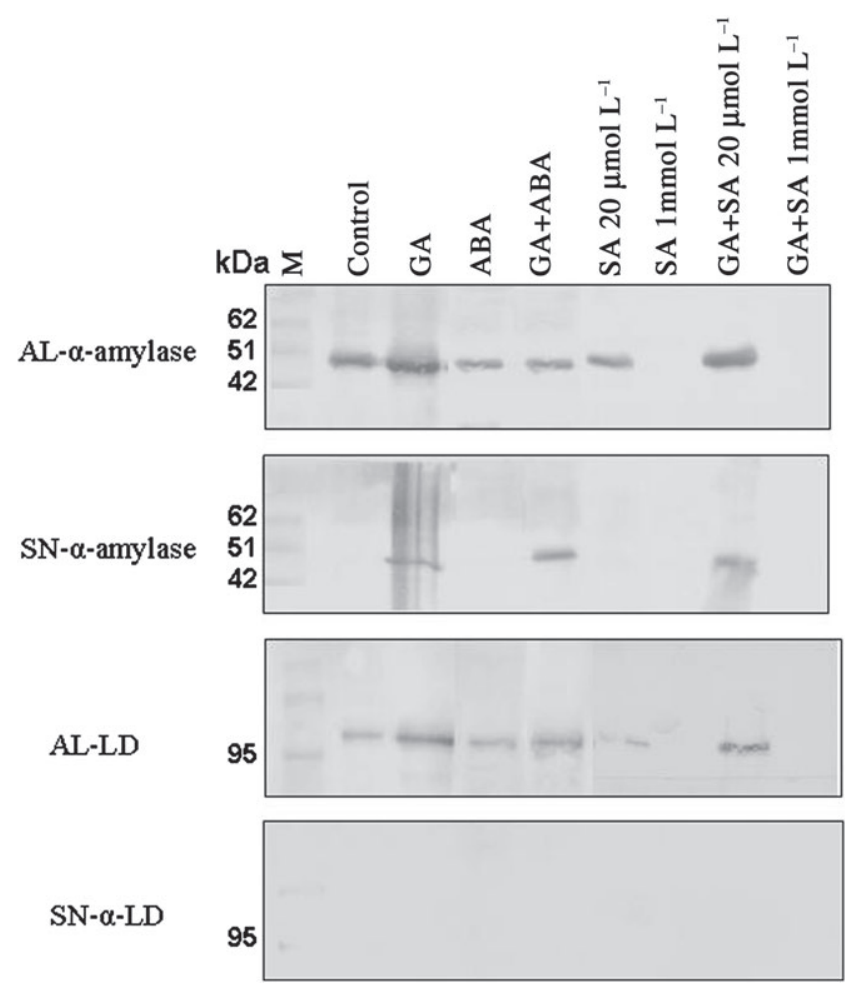

Figure 4. The appearance patterns of $\alpha$-amylase and LD in (A) aleurone layer extracts and culture supernatants of AL-control, AL-GA, AL-ABA, AL-GA+ABA, AL-SA $\left(20 \mu \mathrm{mol} \mathrm{L}^{-1}\right), \mathrm{AL}-\mathrm{SA}\left(1 \mathrm{mmol} \mathrm{L}^{-1}\right), \mathrm{AL}-\mathrm{GA}+\mathrm{SA}(20 \mu \mathrm{mol}$ $\left.\mathrm{L}^{-1}\right)$ and $\mathrm{AL}+\mathrm{SA}\left(1 \mathrm{mmol} \mathrm{L}^{-1}\right)$ after $48 \mathrm{~h}$ incubation. Equal volumes $(18 \mu \mathrm{L})$ of protein extracts from aleurone layer or culture supernatant were loaded on to SDS-PAGE. Limit dextrinase (LD) and $\alpha$-amylase were detected by western blotting.

before treatment with GA (Fig. S1). Low levels of $\alpha$-amylase and LD were also observed in AL-SA $\left(20 \mu \mathrm{mol} \mathrm{L}^{-1}\right)$ after $48 \mathrm{~h}$ incubation. However, these proteins were not detected in AL-SA $\left(1 \mathrm{mmol} \mathrm{L}^{-1}\right)$ (Fig. S2, supporting information).

The aleurone layers were treated in buffers containing a combination of GA with either $20 \mu \mathrm{mol} \mathrm{L}^{-1} \mathrm{ABA}, 20 \mu \mathrm{mol} \mathrm{L}^{-1} \mathrm{SA}$ or $1 \mathrm{mmol}$ $\mathrm{L}^{-1} \mathrm{SA}$ and incubated for $48 \mathrm{~h}$. In comparison to $\mathrm{AL}-\mathrm{GA}$, the levels of $\alpha$-amylase and LD were considerably decreased in aleurone layers treated with $G A+A B A$ and $G A+S A\left(1 \mathrm{mmol} \mathrm{L}^{-1}\right)$, indicating the antagonistic effects of ABA and SA on GA (Fig. 4). However, the amounts of $\alpha$-amylase and LD synthesized in GA-induced aleurone layers were not affected by $20 \mu \mathrm{mol} \mathrm{L}^{-1}$ SA (Fig. 4).

The analysis of culture supernatants showed that $\alpha$-amylase is released from aleurone layer treated with $G A, G A+A B A$ and $\mathrm{GA}+\mathrm{SA}\left(20 \mu \mathrm{mol} \mathrm{L} \mathrm{L}^{-1}\right)$. In contrast, $\alpha$-amylase which was detected in the aleurone layers from AL-control, AL-ABA and AL-SA (20 $\mu \mathrm{mol} \mathrm{L}^{-1}$ ) seems not to be released as it was not detected in the corresponding culture supernatants (Fig. 4). LD, although detected in aleurone layer extracts, was not detected in any of the culture supernatants after $48 \mathrm{~h}$ incubation (Fig. 4), in agreement with the previous observations (Fig. 2B).

\section{DISCUSSION}

In the present time-course analysis we showed that the release of LD from aleurone layer into the culture supernatant is significantly delayed with respect to its detection in the aleurone layer, in contrast to $\alpha$-amylase, which was detected in the supernatant 
shortly after detection in the aleurone layer, suggesting that it is secreted as soon as it is synthesized. Despite its accumulation in aleurone layers, LD was not detected in the supernatant until $72 \mathrm{~h}$, at which time most cells in GA-treated aleurone layers are expected to have undergone PCD. ${ }^{37}$ Supporting these observations, LD was identified in cellular extracts of aleurone layers from cultivar Himalaya after $24 \mathrm{~h}$ incubation with GA, but not in the corresponding secreted protein fraction. ${ }^{38}$ The decrease in protein content of aleurone layers and corresponding increase of proteins in the culture supernatants after $72 \mathrm{~h}$ incubation in GA suggests aleurone layer cell death with cell rupture and release of protein contents, supporting a PCD-dependent release of LD.

The enzyme $\alpha$-amylase has a primary role in degradation of starch in endosperm, whereas LD has a secondary role in starch hydrolysis. In contrast, enzymes like $\beta$-glucanase that are required for degradation of endosperm cell walls and the initial degradation of aleurone layer outer cell walls - allowing access to the starch granules of the starchy endosperm - are the first enzymes to be released from aleurone layers. ${ }^{39}$ Thus the priority of release of these enzymes seems to be consistent with their role in starch degradation. Barley $\alpha$-amylase contains a predicted $\mathrm{N}$-terminal signal peptide directing them for secretion after synthesis. Secretion of $\alpha$-amylase across the plasma membrane is an energy-dependent process, while its passage through the cell wall is diffusion limited ${ }^{40}$ and depends on the presence of cations like $\mathrm{Ca}^{2+}$ (Fig 2B). ${ }^{41}$ In contrast to proteins destined for the classical secretory pathway, LD does not carry a signal peptide predicted to target it to the endoplasmic reticulum (ER). Instead, a 78-amino acid leader sequence at the N-terminus of LD was found to be similar to transit peptides that direct polypeptides to plastids. ${ }^{9}$ This again suggests that a different mechanism operates for release of LD to the starchy endosperm. ${ }^{42}$

Notably, endo- $\beta-1,4$-xylanase, required for degradation of the inner cell wall of aleurone layers, also lacks a predicted N-terminal signal peptide and its release from aleurone layers also coincides with PCD. ${ }^{2}$ Thus aleurone layer tissue integrity is maintained until secretion of $\alpha$-amylase and other hydrolases is completed. Endo- $\beta-1,4$-xylanase is produced as an inactive precursor that requires the action of cysteine proteinases for processing to an active form. ${ }^{2}$ Cysteine proteinases are activated in aleurone layer protein storage vesicles (PSVs) by a GA-induced decrease in vacuolar $\mathrm{pH}^{43}$ Conversion of LD in barley grain extracts from a bound, inactive form to a free, active form also involves the action of cysteine proteases, ${ }^{36}$ although the nature of the bound and free LD remains to be understood. In this respect it would be interesting to determine whether release of LD from barley aleurone layers was

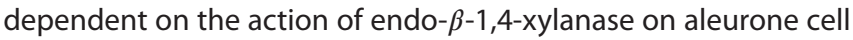
walls.

Although the kinetics and timing of enzyme release from the aleurone might differ in the context of the intact, germinating grain, the evidence presented here suggests that even if LD is synthesized in aleurone layers at a relatively early time point after GA treatment, it is not released from aleurone layers for starch degradation until much later. This implies that merely increasing the amount of LD produced during seed germination is not sufficient to improve total starch hydrolysis, but that targeting of the protein to the starchy endosperm also needs to be addressed. The interplay of endogenous enzyme activities with enzymes originating from the microbiota that naturally populate the barley grains may also influence endosperm modification.

It is well known that ABA and SA antagonize GA-promoted amylase expression. In this study we observed that amounts of both $\alpha$-amylase and LD decreased in AL-GA + ABA and AL-GA + SA (20 $\mu \mathrm{mol} \mathrm{L^{-1 } )}$ compared to AL-GA. A high concentration of SA (1 mmol $\mathrm{L}^{-1}$ ) completely suppressed the production of $\alpha$-amylase and LD. This work also demonstrates that low levels of $\alpha$-amylase and LD appear in the aleurone layer during incubation in AL-ABA and AL-SA $\left(20 \mu \mathrm{mol} \mathrm{L}^{-1}\right)$ as well as control samples. Nevertheless, $\alpha$-amylase was only detected in corresponding culture supernatants of $A L-G A, A L-G A+A B A$ and $A L-G A+S A$ and was not detected in culture supernatants of AL-control, AL-ABA or AL-SA. This result may indicate that the release of $\alpha$-amylase is not inhibited by ABA and SA but is dependent on the presence of GA. This may be due to a requirement for xylanase and glycosidases, synthesized in the aleurone layer in response to GA, for degradation of aleurone layer cell walls. ${ }^{44}$

\section{SUPPORTING INFORMATION}

Supporting information may be found in the online version of this article.

\section{REFERENCES}

1 Ritchie S, Swanson SJ, Gilroy S, Physiology of the aleurone and starchy endosperm during grain development and early seedling growth: new insights from cell and molecular biology. Seed Sci Res 10:193-222 (2000).

2 Caspers MP, Lok F, Sinjorgo KM, Van Zeijl MJ, Nielsen KA Cameron-Mills V, Synthesis, processing and export of cytoplasmic endo-beta-1,4-xylanase from barley aleurone during germination. Plant J 26:191-204 (2001).

3 Bewley JD and Black M, Seeds: Physiology and Development of Germination. Plenum, New York (1994).

4 Mundy J and Rogers JC, Selective expression of a probable amylase/protease inhibitor in barley (Hordeum vulgare) aleurone cells: comparison to the barley amylase/subtilisin inhibitor. Planta 169:51-63 (1986).

5 Manners DJ, Some aspects of the metabolism of starch. Cereal Foods World 30:722-727 (1985).

6 Sun ZT and Henson CA, A quantitative assessment of the importance of barley seed $\alpha$-amylase, $\beta$-amylase, debranching enzyme, and $\alpha$-glucosidase in starch degradation. Arch Biochem Biophys 284:298-305 (1991).

7 Frandsen TP and Svensson B, Plant alpha-glucosidases of the glycoside hydrolase family 31: molecular properties, substrate specificity, reaction mechanism, and comparison with family members of different origin. Plant Mol Biol 37:1 - 13 (1998).

8 Schroeder SW and MacGregor A, Synthesis of limit dextrinase in germinated barley kernels and aleurone tissues. J Am Soc Brew Chem 56:32-37 (1998).

9 Burton RA, Zhang XQ, Hrmova M and Fincher B, A single limit dextrinase gene is expressed both in the developing endosperm and in germinated grains of barley. Plant Physiol 119:859-871 (1999).

10 MacGregor EA, The proteinaceous inhibitor of limit dextrinase in barley and malt. Biochim Biophys Acta 1696:165-170 (2004).

11 MacGregor AW, Bazin SL and Schroeder SW, Effect of starch hydrolysis products on the determination of limit dextrinase and limit dextrinase inhibitors in barley and malt. J Cereal Sci 35:17-28 (2002).

12 Hara-Nishimura L, Nishimura M and Daussant J, Conversion of free $\beta$-amylase to bound $\beta$-amylase on starch granules in the barley endosperm during desiccation phase of seed development. Protoplasma 134:149-153 (1986).

13 Shewry PR, Parmar S, Buxton B, Gale MD, Liu CJ, Hejgaard J and Kreis $\mathrm{M}$, Multiple molecular forms of $\beta$-amylase in seeds and vegetative tissue of barley. Planta 176:127-134 (1988).

14 Hejgaard J, Free and bound $\beta$-amylases during malting of barley: characterization by two-dimensional immunoelectrophoresis. J Inst Brew 84:43-46 (1978).

15 Ho THD, Gomez-Cadenas A, Zentella R and Casaretto J, Crosstalk between gibberellin and abscisic acid in cereal aleurone. $J$ Plant Growth Regul 22:185-194 (2003). 
16 Achard P, Cheng H, Grauwe L, Decat J, Schoutteten H, Moritz T et al., Integration of plant responses to environmentally activated phytohormonal signals. Science 311:91-94 (2006).

17 Spoel SH and Dong X, Making sense of hormone crosstalk during plant immune responses. Cell Host Microbe 3:348-351 (2008).

18 Tuteja N and Sopory SK, Chemical signaling under abiotic stress environment in plants. Plant Signal Behav 3:525-536 (2008).

19 Vlot AC, Dempsey DA and Klessig DF, Salicylic acid, a multifaceted hormone to combat disease. Annu Rev Phytopathol 47:177-206 (2009).

20 Wolters $\mathrm{H}$ and Jurgens G, Survival of the flexible: hormonal growth control and adaptation in plant development. Nat Rev Genet 10:305-317 (2009).

21 Yasuda M, Ishikawa A, Jikumaru Y, Seki M, Umezawa T, Asami T et al., Antagonistic interaction between systemic acquired resistance and the abscisic acid-mediated abiotic stress response in Arabidopsis. Plant Cell 20:1678-1692 (2009).

22 Alonso-Ramírez A, Rodríguez D, Reyes D, Jiménez JA, Nicolás G, López-Climent M et al., Evidence for a role of gibberellins in salicylic acid-modulated early plant responses to abiotic stress in Arabidopsis seeds. Plant Physiol 150:1335-1344 (2009).

23 Rajjou L, Belghazi M, Huguet R, Robin C, Moreau A, Job C et al., Proteomic investigation of the effect of salicylic acid on arabidopsis seed germination and establishment of early defense mechanisms. Plant Physiol 141:910-923 (2006).

24 Guan L and Scandalios JG, Developmentally related responses of maize catalase genes to salicylic acid. Proc Natl Acad Sci USA 92:5930-5934 (1995).

25 Nishimura N, Kitahata N, Seki M, Narusaka Y, Narusaka M, Kuromori $\mathrm{T}$ et al., Analysis of ABA hypersensitive germination revealed the pivotal functions of PARN in stress response in Arabidopsis. Plant $J$ 44:972-984 (2005).

26 Xie Z, Zhang ZL, Hanzlik S, Cook E and Shen QJ, Salicylic acid inhibits gibberellin-induced alpha-amylase expression and seed germination via a pathway involving an abscisic-acid-inducible WRKY gene. Plant Mol Biol 64:293-303 (2007).

27 Østergaard O, Melchior S, Roepstorff P and Svensson B, Initial proteome analysis of mature barley seed and malt. Proteomics 2:733-739 (2002).

28 Østergaard O, Finnie C, Laugesen S, Roepstorff P and Svensson B, Proteome analysis of barley seeds: identification of major proteins from two-dimensional gels (pl4-7). Proteomics 4:2437-2447 (2004).

29 Bønsager BC, Finnie C, Roepstorff P and Svensson B, Germination and radical elongation in barley tracked using proteome analysis of dissected embryo, aleurone layer and endosperm tissues. Proteomics 7:4538-4540 (2007).

30 Bradford MM, Rapid and sensitive method for the quantitation of microgram quantities of protein utilizing the principle of protein-dye binding. Anal Biochem 72:248-254 (1976).

31 Heukeshoven J and Dernick R, Improved silver staining procedure for fast staining in PhastSystem Development Unit. I. Staining of sodium dodecyl sulfate gels. Electrophoresis 9:28-32 (1998).

32 Kristensen M, Planchot V, Abe J and Svensson B, Large-scale purification and characterization of barley limit dextrinase, a member of the $\alpha$-amylase structural family. Cereal Chem 75:473-479 (1998).

33 Bethke PC, Lonsdale JE, Fath A and Jones RL, Hormonally regulated programmed cell death in barley aleurone cells. Plant Cell 11:1033-1045 (1999).

34 Rogers JC, Two barley $\alpha$-amylase gene families are regulated differentially in aleurone cells. J Biol Chem 260:3731-3738 (1985).

35 Sissons MJ, Lancer RCM, Sparrow DHB, Studies on limit dextrinase in barley. 3. Limit dextrinase in developing kernels. J Cereal Sci 17:19-24 (1993).

36 Longstaff MA and Bryce JH, Development of limit dextrinase in germinated barley (Hordeum vulgare L.). Plant Physiol 101:881-889 (1993).

37 Bethke PC, Fath A, Spiegel YN, Hwang Y and Jones RL, Abscisic acid, gibberellin and cell viability in cereal aleurone. Euphytica 126:3-11 (2002).

38 Finnie C, Andersen B, Shahpiri A and Svensson B, Proteomes of the barley aleurone layer: a model system for plant signaling and protein secretion. Proteomics 11:1595-1605 (2011).

39 Fincher GB, Cell wall metabolism in barley, in Barley: Genetics, Biochemistry, Molecular Biology and Biochemistry, ed. by Shewry PR. CAB International, Wallingford UK, pp. 413-437 (1992).

40 Varner JE and Mense RM, Characteristics of the process of enzyme release from secretory plant cells. Plant Physiol 49:187-189 (1972).

41 Benjamin AM and Jones RL, $\alpha$-Amylase secretion by single barley aleurone layer. Plant Physiol 70:1149-1155 (1982).

42 Ding SH, Liu YS, Zeng Y, Himmel ME, Baker JO and Bayer EA, How does plant cell wall nanoscale architecture correlate with enzymatic digestibility? Science 338:1055-1060 (2012).

43 Swanson SJ and Jones RL, Gibberellic acid induced vacuolar acidification in barley aleurone. Plant Cell 8:2211-2221 (1996).

44 Taiz $L$ and Hinigman WA, Production of cell wall hydrolyzing enzymes by barley aleurone layer in response to gibberellic acid. Plant Physiol 58:380-386 (1976). 